\title{
Prevention of ingestion injuries in children
}

\author{
M Arnold, ${ }^{1} \mathrm{MB} \mathrm{ChB}, \mathrm{DCH}(\mathrm{SA}), \mathrm{FCPaedSurg}(\mathrm{SA})$, MMed (PaedSurg); A B van As, ${ }^{2} \mathrm{MB}$ ChB, MMed, MBA, FCS PhD; \\ A Numanoglu, ${ }^{1} \mathrm{MB} \mathrm{ChB}, \mathrm{FCS}(\mathrm{SA})$ \\ ${ }^{1}$ Division of Paediatric Surgery, Red Cross War Memorial Children's Hospital and University of Cape Town, South Africa \\ ${ }^{2}$ Childsafe, Cape Town; and Trauma Unit, Red Cross War Memorial Children's Hospital and Division of Paediatric Surgery, \\ Faculty of Health Sciences, University of Cape Town, South Africa
}

Corresponding author: A B van As (sebastian.vanas@uct.ac.za)

\begin{abstract}
Accidental caustic and foreign body ingestion by young children lead to a high number of emergency department visits, especially in lower- and middle-income countries. Some of these cause minimal tissue injury or pass spontaneously and uneventfully through the gastrointestinal tract; others may cause major morbidity, or rarely mortality. Increased primary prevention of ingestion through community awareness and vigilant childcare in addition to legislative steps to ensure a safe environment for these vulnerable members of society are needed. Secondary prevention of long-term sequelae through timely and appropriate assessment and referral for endoscopy, laparotomy or other treatments can limit morbidity where primary prevention fails. Basic guidelines for management principles are suggested. Social lobby is required to further reform commercial risks to children in addition to creating caregiver awareness of common environmental hazards, particularly in developing countries such as South Africa.
\end{abstract}

S Afr Med J 2017;107(3):183-187. DOI:10.7196/SAMJ.2017.v107i3.12365

Swallowing of non-food substances is common in toddlers and the preschool age group. Coin ingestion alone has been reported in as many as $4 \%$ of children, with $15 \%$ of their parents seeking healthcare. ${ }^{[1]}$ Caustic ingestion affects $5-518 / 100000$ people per year, largely in less industrialised nations. ${ }^{[2,3]}$ Distress and a healthcare consultation also occasionally result from choking on age-inappropriate food items (typically hard sweets or large chunks of meat) or bones (especially fish bones ${ }^{[4]}$ ), and accidental medication ingestion. At Red Cross War Memorial Children's Hospital, nearly two of three ingested foreign bodies require endoscopic or surgical removal. ${ }^{[5]}$ Endoscopic grading of injury under general anaesthesia is required in $40 \%$ of children who present with caustic ingestion. ${ }^{[6]}$ Ingestion of multiple magnets results in bowel perforations in at least half of children affected. ${ }^{[7]}$ Primary prevention through education and awareness is crucial to reduce the substantial healthcare burden that such incidents present.

The majority of these accidental ingestions occur in the home and nearby areas. ${ }^{[8]}$ Conditions that carry an increased risk of ingestion/ aspiration include attention-deficit hyperactivity syndrome, ${ }^{[9]}$ low levels of parental education, ${ }^{[9,10]}$ young mothers, ${ }^{[8]}$ lack of parental supervision, ${ }^{[8]}$ and rural abode ${ }^{[11]}$ Male gender predominance is an inconstant finding. ${ }^{[5,9,12-14]}$ Curiosity, exploration of the developing oral phase, the child's inexperience and limited understanding of the environment combined with inadequate caregiver supervision put children under- $5^{[15]}$ at the highest risk of injury from ingested foreign bodies and caustic substances, with a peak incidence at 3 years of age..$^{[5]}$

A child may present acutely with peri-oral inflammation, dysphagia, drooling, cough, stridor, hoarseness, vomiting or signs of peritonitis. A history of such ingestion may be absent, as ingestion is witnessed in as few as a quarter of all cases, ${ }^{[16]}$ making timely diagnosis and treatment challenging. Peri-oral burns may cause dysphagia and drooling lasting a few hours to weeks. These external signs do not reliably predict oesophageal penetration. Other symptoms include respiratory distress, e.g. from ingestion of volatile agents (e.g. paraffin, hydrocarbons), which may require temporary oxygen support. Fullthickness oesophageal necrosis with subsequent mediastinitis and gastric necrosis with perforation and peritonitis fortunately occur very rarely in children, as intake is usually accidental, substances are not very potent and volumes ingested are thus usually limited by the unpleasant taste.

Household cleaning agents are the most common causative chemical agents, usually because of unsafe storage or use while small children are ill-advisedly allowed in the vicinity. The most commonly ingested chemical is an oxidising agent, such as peroxide or chloride bleach, with domestically retailed concentrations causing only superficial redness and mild oedema. These are therefore not a major risk factor for oesophageal strictures; nevertheless, they result in a significant number of visits to emergency departments although more than symptomatic treatment is usually not required. ${ }^{[12]}$ More concentrated agents used in industrial or agricultural contexts may be ingested, particularly in rural areas. ${ }^{[1]}$

\section{Complications}

Ingestion of a strong alkali ( $\mathrm{pH} \geq 11.5)$, strong acid ( $\mathrm{pH} \leq 2)$ or oxidising agent, and mixtures of these, will cause chemical burns in $20-40 \%$ of children ${ }^{[17,18]}$ Injury depends on the chemical concentration and volume, the tissue surface area and the duration of exposure. Among the most common serious long-term sequelae is oesophageal stricture formation $(7-25 \%),{ }^{[12,17]}$ which occurs when submucosal penetration of the burn involves $>50 \%$ of the lumen.

Foreign body perforation and/or obstruction of the gastrointestinal tract (GIT) typically occurs proximal to normal anatomical narrowing, i.e. (i) the cricopharynx, which is the narrowest part of the child's upper GIT (Fig. 1); (ii) the upper third of the oesophagus, where the left main bronchus and aortic arch cross anteriorly with the vertebral bodies posteriorly (Fig. 2); (iii) the oesophagogastric junction (lower oesophageal sphincter); (iv) the pylorus (Fig. 3); ( $v$ ) the duodenum at the ligament of Treitz; and ( $v i)$ the ileocaecal valve.

Dangerous ingested foreign bodies include sharp objects that can penetrate the GIT, and blunt objects that may cause partial or complete GIT obstruction and pressure necrosis. Ingestion of $\geq 2$ magnets can rapidly cause entero-enteric fistulas (Fig. 4), with $85 \%$ requiring removal by means of endoscopy, laparoscopy or laparotomy. ${ }^{[19]}$ Electric disc cells (commonly known as button 


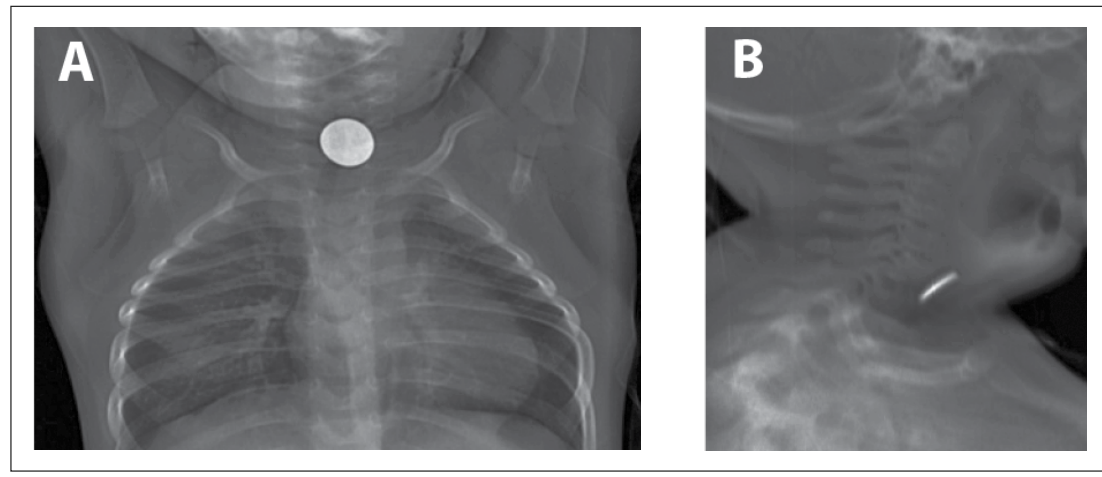

Fig. 1. (A) Anteroposterior and (B) lateral low-dose radiograph (Lodox, SA), demonstrating the classic appearance of a coin stuck in the cricopharynx, the narrowest part of a child's GIT. Although foreign bodies in both the upper oesophagus and the trachea of a child may cause stridor, compression between the C-shaped rings of the trachea anteriorly and the vertebral bodies causes the 'face-on' appearance on anteroposterior imaging, differentiating it from a coin in the trachea that would be 'end-on'.
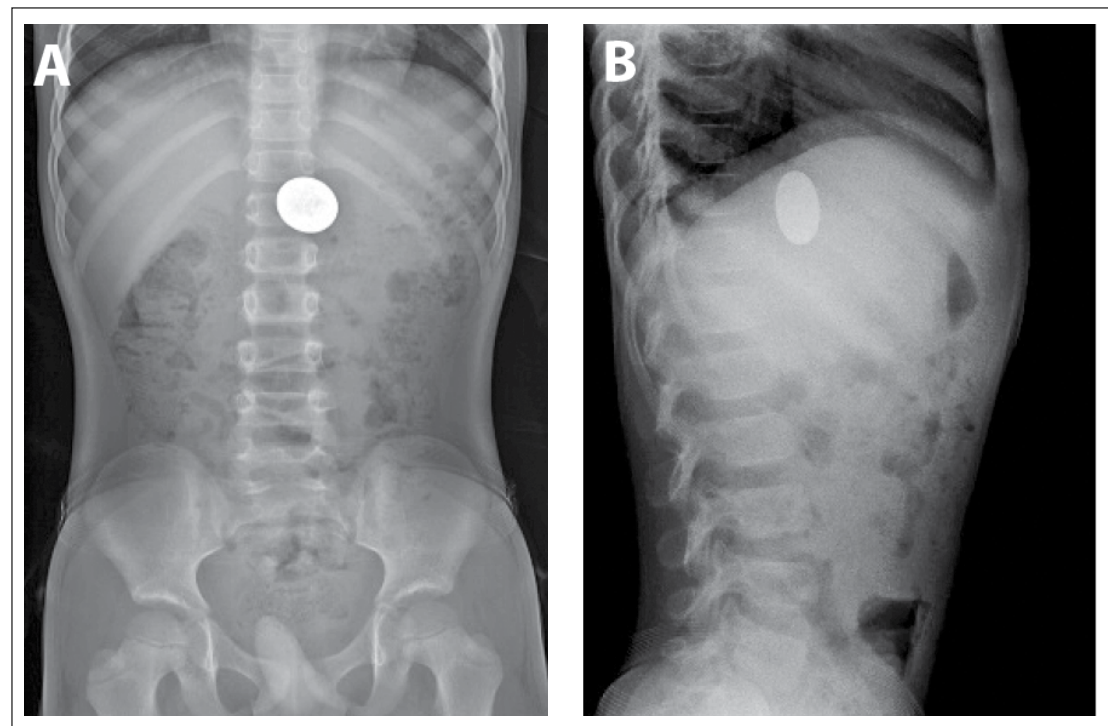

Fig. 3. (A) Anteroposterior and (B) lateral abdominal radiographs demonstrating a five rand coin $(25 \mathrm{~mm}$ diameter) unable to pass the pylorus 2 weeks after ingestion by a 2-year-old boy. The position in the stomach rather than the transverse colon is confirmed by the lateral abdominal radiograph. Endoscopic retrieval was required.

batteries) can cause focal oesophageal burns within an hour in animal studies, while residual activity in used and discarded batteries can still cause significant hydrolysis of tissue. ${ }^{[20]}$ If the narrow negative pole lies anteriorly, risk of perforation with mediastinitis, trachea-oesophageal fistula formation, erosion into great mediastinal vessels (e.g. oesophago-aortic fistulas) and long-term oesophageal stricture formation escalate significantly, especially when extraction is delayed $>15$ hours after ingestion. ${ }^{[21-23]}$

Coins remain the most commonly ingested foreign body ${ }^{[5,24]}$ locally and internationally, followed by other plastic and metal objects, especially toy parts. Most $(>80 \%)$ round objects such as coins, marbles and button batteries are likely to pass through the rest of the GIT spontaneously and unevent- fully if they have traversed the cricopharynx. ${ }^{[25,26]}$ Fortunately, most foreign bodies $(>80 \%)$ are radio-opaque. ${ }^{[5,16]}$ Fluoroscopy and occasionally sonography may be useful to detect radiolucent objects, but a low index of suspicion is required for endoscopic evaluation in these cases.

Oesophageal motility and patency may be impaired by previous oesophageal surgery (e.g. oesophageal atresia repair, peptic or caustic stricture dilations and gastric fundoplication) and increase the risk of a food bolus (notably meat or fibrous fruit, such as citrus) or a foreign body impacting in the oesophagus and causing dysphagia and regurgitation of food. Prolonged impaction of an unrecognised foreign body in this context can aggravate existing oesophageal strictures through pressure necrosis.

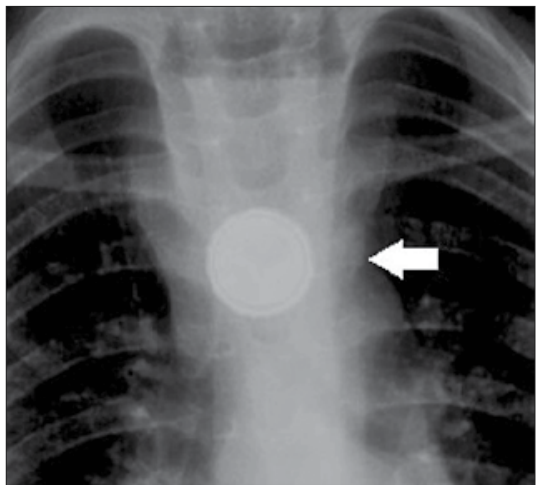

Fig. 2. Electric cell (commonly called a button battery) lodged in the upper oesophagus, which eroded into the aortic arch. The halo appearance of the battery edge differentiates it from a coin, and mandates urgent removal.

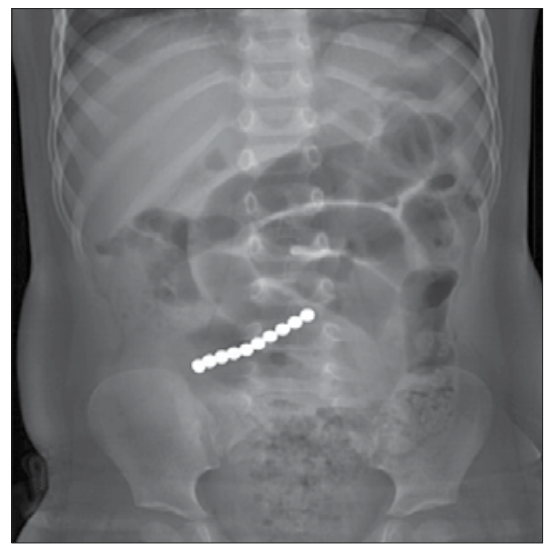

Fig. 4. AP low-dose radiograph (Lodox, SA) of the abdomen, demonstrating multiple small magnetic balls ingested by a 2-year-old boy without his parents' knowledge. Dilated bowel loops with a thickened bowel wall demonstrate obstruction. Endoscopic-assisted laparotomy revealed magnets in the caecum, jejunum and duodenum, with multiple bowel perforations from magnets adhering to each other through bowel loops.

\section{Preventive strategies}

Public education about the importance of appropriate supervision of small children and the risks imposed in the environment is most important. Public health awareness campaigns using various media are also required to lobby governments to legislate appropriate safety regulations locally.

Lobbying has led to the development and implementation of protective legislation in developed countries. While South Africa (SA) has benefited from legislation overseas, with a trickle-down effect into our local markets, consumers remain vulnerable to less scrupulous manufacturers. While this has had positive spin-offs in SA, with many local companies voluntarily implementing these steps, legislation and enforcement in SA remain limited. Examples include the following: 
- Child-proof bottle tops, requiring application of focal pressure in addition to unscrewing the cap, and spray-bottle safety catches on household detergents.

- Limitation on $\mathrm{pH}$ of detergents marketed for domestic use.

- Restriction of toys marketed for children $\leq 3$ years old to a minimum of $3 \mathrm{~cm}$ in diameter.

- Secure battery compartments for motorised toys and hearing aids. ${ }^{[18]}$

- Package labelling requirements, e.g. regarding content of chemicals in household use, associated health risks with ingestion, and first-aid advice, including poison centre contact details; warning on packaging of any smaller object to prevent access by children $<3$ years because of aspiration or swallowing risk.

- Dangerous product recall, e.g. of small ( 3 - $5 \mathrm{~mm}$ diameter), strong rare-earth (neodymium) balls marketed as 'executive' toys (Fig. 4$)$ in the USA. ${ }^{[19,27]}$

Examples of unresolved challenges to primary prevention locally and elsewhere include:

- Ongoing household use of strong industrial-strength caustic agents, often illegally sold or decanted and stored in nondescript containers or recycled cold-drink containers, is of great concern. Thirsty children may seek these out or be given these by unsuspecting older siblings, particularly in hot weather, with devastating consequences.

- Marketing, using brightly coloured packaging, has brought new risks to the fore in the past few decades, e.g. automated dishwasher detergent pods, which have caused an upsurge in associated caustic oesophageal injuries in developed countries, ${ }^{[28]}$ although fortunately significant injury occurs in $<5 \%$ of cases. ${ }^{[2]}$

Partnership with civil society to identify and mitigate the risks posed to children by these common environmental exposures is crucial. Organisations such as the Child Accident Prevention Foundation of Southern Africa (Childsafe) have been highly instrumental in promoting protective legislation and community awareness. Acknowledgement of the vulnerability of children and the creation of a community culture of protection have consequently grown significantly.

Creative resolutions to risks exist, but require social lobby of manufacturers, retailers and government to promote implementation of suitable marketing innovations and legislative reforms. Traditional print and social media activism remains a relatively under-tapped resource in this regard. For example, retailers of magnet toys could be encouraged to enclose them in a malleable child-proof outer shell. Some retail stores have taken the initiative to promote recycling of high-voltage lithium-ion electric cells; such initiatives could be expanded to include a safety campaign regarding disposal of all discharged used batteries. Warnings of the hazards of accidental swallowing of 'mouthed' small non-food objects by young children could be emphasised in the national Road to Health booklet provided to all children in the government sector and at clinic visits.

Major consequences of ingestion injuries are rare $(<1 \%),{ }^{[5]}$ but children may incur major morbidity (e.g. tracheostomy, emergency thoracotomy, multiple oesophageal stricture dilatations, oesophageal replacement procedures, and bowel resection) and even mortality as a result. Secondary prevention of sequelae of caustic ingestion by caregivers and healthcare providers includes awareness of the risks posed by various items and agents, and timeous and appropriate removal of the object where indicated, follow-up, or other treatment. A summary of important common agents of ingestion injuries and a brief guideline to their associated management are given Table 1 . Early consultation with the nearest poison call centre and tertiary paediatric institution allows identification of the nature of potentially harmful chemicals and appropriate care.

\section{Conclusion}

Ingestion injuries remain extremely common in developing countries, unlike some countries in the developed world, where progressive legislation and community awareness foster a culture of vigilance against the risks of gastrointestinal injury in children by accidental injury by non-food substances. These highly preventable injuries are an unnecessary healthcare burden. Limitation of risk factors is achievable with partnership by government, health authorities and non-governmental agencies to identify potential hazards, legislate against commercial risks and warn the public about how these injuries occur.

1. Conners GP, Chamberlain JM, Weiner PR. Pediatric coin ingestion: A home-based survey. Am J Emerg Med

1995:13(6):638-640. http://dx.doi.org/10.1016/0735-6757(95)90047-0
2. Christesen HB. Epidemiology and prevention of caustic ingestion in children. Acta Paed 1994:83(2):212-215.

2. Christesen HB. Epidemiology and prevention of caustic ingestion in children. Acta Paed 1994;83(2):212-215.
3. Othman N, Kendrick D. Epidemiology of burn injuries in the East Mediterranean Region: A systematic Othman N, Kendrick D. Epidemiology of burn injuries in the East Mediterranean Regi
review. BMC Public Health 2010;10(1):83. http://dx.doi.org/ 10.1186/1471-2458-10-83

4. Lim CW, Park MH, Do HJ, et al. Factors associated with removal of impacted fishbone in children, suspected ingestion. Pediatr Gastroenterol Hepatol Nutr 2016;19(3):168-174. http://dx.doi.org/10.5223/ pghn.2016.19.3.168

5. Van $\mathrm{As} \mathrm{AB}$, du Toit $\mathrm{N}$, Wallis $\mathrm{L}$, et al. The South African experience with ingestion injury in children. Int Pediatr Otorhinolaryngol 2003;67(Suppl 1):S175-S178. http://dx.doi.org/10.17140/EMOJ-1-105

6. Janssen TL, van Dijk M, van As AB, et al. Cost-effectiveness of the sucrulfate technetium $99 \mathrm{~m}$ isotopelabelled esophagal scan to assess esophageal injury in children after caustic ingestion. Emerg Med Open J 2015;1(1):17-21.

7. Waters AM, Teitelbaum DH, Thorne V, et al. Surgical management and morbidity of pediatric magnet ingestions. J Surg Res 2015:199(1):137-140. http://dx.doi.org/10.1016/j.jss.2015.04.007 8. Sanchez-Ramirez CA, Larrosa-Haro A, Vasquez-Garibay EM, et al. Socio-demographic factors associated with caustic substance ingestion in children and adoles

9. Cakmak M, Göllü G, Boybeyi Ö, et al. Cognitive and behavioural aspects of children with caustic 9. Çakmak M, Göllü G, Boybeyi O, et al. Cognitive and behavioural aspects of children with
ingestion. J Pediatr Surg 2015;50(4):540-542. http://dx.doi.org/10.1016/j.jpedsurg.2014.10.052

10. Sarioglu-Buke A, Corduk N, Atesci F, et al. A different aspect of corrosive ingestion in children: Socio-demographic characteristics and effect of family functioning. Int J Pediatr Otorhinolaryngo 2006;70(10):1791-1798. http://dx.doi.org/10.1016/j.ijporl.2006.06.005

11. Neidich G. Ingestion of caustic alkali farm products. J Pediatr Gastroenterol Nutrition 1993;16(1):75-77.

12. Karaman I, Koç O, Karaman A, et al. Evaluation of 968 children with corrosive substance ingestion. Indian J Crit Care Med 2015;19(12):714-718. http://dx.doi.org/10.4103/0972-5229.171377

3. Riffat $F$, Cheng A. Pediatric caustic ingestion: 50 consecutive cases and a review of the literature. Disease Esofagus 2009;22(1):89-94. http://dx.doi.org/10.1111/j.1442-2050.2008.00867.x

14. Eskander AE, Sawires HK, Ebeid BA. Foreign-body ingestion in Egyptian children: A 10-year experience of endoscopic intervention in a tertiary hospital. Minerva Pediatr 2016. 15. Rafeey M, Ghojazadeh M, Mehdizadeh A, et al. Intercontinental comparison of caustic ingestion in
children. Korean J Pediatr 2015;58(12):491. http://dx.doi.org/10.3345/kjp.2015.58.12.49

16. Sink JR,Kitsko DJ, Mehta DK, et al. Diagnosis of pediatric foreign body ingestion: Clinical presentation physical examination and radiologic findings. Ann Otol Rhinol Laryngol 2016;125(4):342-350. http://
phis physical examination and radiologic $\mathrm{f}$
dx.doi.org/10.1177/0003489415611128

17. Tiryaki T, Livanelioğlu Z, Atayurt H. Early bougienage for the relief of stricture formation following caustic esophageal burns. Pediatr Surg Int 2005;21(2):78-80. http://dx.doi.org/10.1007/s00383-004-1331-3

18. Millar AJ, Cox SG. Caustic injury of the oesophagus. Pediatr Surg Int 2015;31(2):111-21. http://dx.doi. org/10.1007/s00383-014-3642-3

19. Kramer RE, Lerner DG, Lin T, et al. Management of ingested foreign bodies in children: A clinical report of the NASPGHAN Endoscopy Committee. J Pediatr Gastroenterol Nutrition 2015;60(4):562574. http://dx.doi.org/10.1097/mpg.0000000000000729

20. Jatana KR, Litovitz T, Reilly JS, et al. Pediatric button battery injuries: 2013 task force update. Int $J$ Pediatr Otorhinolaryngol 2013;77(9):1392-1399. http://dx.doi.org/10.1016/j.ijporl.2013.06.006

21. Ettyreddy AR, Georg MW, Chi DH. Button battery injuries in the pediatric aerodigestive tract. Ear Nose Throat J 2015;94(12):486-493.

22. Buttazzoni E, Gregori D, Paoli B, et al. Symptoms associated with button batteries injuries in children An epidemiological review. Int J Pediatr Otorhinolaryngol 2015;79(12):2200-2207. http://dx.doi An epidemiological review. Int
org/10.1016/j.ijporl.2015.10.003

23. Leinwand $\mathrm{K}$, Brumbaugh DE, Kramer RE. Button battery ingestion in children: A paradigm for management of severe pediatric foreign body ingestions. Gastrointest Endosc Clin N Am 2016;26(1):99-118. http://dx.doi.org/10.1016/j.giec.2015.08.003

24. Panieri E, Bass DH. The management of ingested foreign bodies in children: A review of 663 cases. Eur J Emerg Med 1995;2(2):83-87.

25. Pugmire BS, Lin TK, Pentiuk S, et al. Imaging button battery ingestions and insertions in children: A 15 year single center review. Pediatr Radiol 2017;47(2):178-185. http://dx.doi.org/10.1007/s00247-016-3751-3 26. Litovitz T, Whitaker N, Clark L. Preventing battery ingestions: An analysis of 8648 cases. Pediatric 2010;125(6):1178-1183. http://dx.doi.org/10.1542/peds.2009-3038

27. Alfonzo MJ, Baum CR. Magnetic foreign body ingestions. Pediatr Emerg Care 2016;32(10):698-702 http://dx.doi.org/10.1097/PEC.0000000000000927

28. Nuutinen M, Uhari M, Karvali T. Consequences of caustic ingestions in children. Acta Paediatr 1994;83(11):1200-1205. http://dx.doi.org/10.1111/j.1651-2227.1994.tb18281.x 
Table 1. Commonly ingested and potentially harmful non-food items and management principles ${ }^{[1,20,26]}$

\begin{tabular}{|c|c|c|c|c|}
\hline Ingested object/agent & $\begin{array}{l}\text { High-risk features for tissue } \\
\text { injury }\end{array}$ & Initial management & Referral criteria & Follow-up \\
\hline Unknown & $\begin{array}{l}\text { Any stridor or history of } \\
\text { cyanosis after ingestion of } \\
\text { a foreign body. }\end{array}$ & $\begin{array}{l}\text { Bronchoscopy in addition to } \\
\text { oesophagoscopy should be } \\
\text { considered even if there are } \\
\text { no clinical signs or there is } \\
\text { no radiological evidence of a } \\
\text { foreign body; more than one } \\
\text { foreign body may have been } \\
\text { ingested. }\end{array}$ & $\begin{array}{l}\text { Sudden-onset stridor or } \\
\text { cyanotic episode. }\end{array}$ & $\begin{array}{l}\text { Advise parents to return } \\
\text { if pyrexia present, any } \\
\text { respiratory symptoms } \\
\text { (e.g. stridor, lower-respiratory } \\
\text { tract infection) or signs } \\
\text { of chest/abdominal pain } \\
\text { or vomiting/drooling if } \\
\text { radiological investigations } \\
\text { and endoscopy negative. }\end{array}$ \\
\hline Sharp objects & $\begin{array}{l}\text { Objects }>50-60 \mathrm{~mm} \\
\text { (consider in under- } 5 \\
\text { children); non-linear shape } \\
\text { (e.g. open safety pin: risk } \\
\text { for obstruction at pylorus or } \\
\text { ileocaecal valve). }\end{array}$ & $\begin{array}{l}\text { Urgent endoscopic removal } \\
\text { if oesophageal or gastric } \\
\text { position. } \\
\text { Observe in hospital } \\
\text { if asymptomatic and } \\
\text { beyond stomach; for small } \\
\text { subdiaphragmatic objects } \\
\text { patient may be discharged } \\
\text { on advice to return if any } \\
\text { symptoms develop (likely } \\
\text { to disappear on own). } \\
\text { Osmotic laxatives } \\
\text { (e.g. lactulose, sorbitol) may } \\
\text { be prescribed but are of no } \\
\text { proven benefit. }\end{array}$ & $\begin{array}{l}\text { Any symptoms, including } \\
\text { abdominal pain, tenderness } \\
\text { or peritonism; signs of } \\
\text { bowel obstruction or } \\
\text { thickened bowel loops } \\
\text { on plain-film abdominal } \\
\text { X-ray; urgent endoscopic } \\
\text { removal required if lodged } \\
\text { above level of diaphragm } \\
\text { on chest X-ray or } \\
\text { pneumoperitoneum. }\end{array}$ & $\begin{array}{l}\text { Repeat X-ray imaging for } \\
\text { radio-opaque objects not } \\
\text { observed in the stool in } \\
3 \text { days. } \\
\text { Consider more frequent } \\
\text { imaging for riskier large/ } \\
\text { longer items. }\end{array}$ \\
\hline Blunt objects & $\begin{array}{l}\text { Objects }>20-\leq 25 \mathrm{~mm} \\
\text { (especially in under-5 } \\
\text { children); or oesophageal } \\
\text { position, e.g. coin lodged at } \\
\text { cricopharynx (level of } \\
\sim 6 \text { th cervical vertebra on } \\
\text { X-ray). }\end{array}$ & $\begin{array}{l}\text { Oesophageal: remove } \\
\text { urgently (e.g. within } \\
24 \text { hours if coin; within next } \\
\text { hour if button battery). } \\
\text { Subdiaphragmatic: observe } \\
\text { if asymptomatic; expect } \\
\text { passage in stools within } \\
\sim 3 \text { days. }\end{array}$ & As described above. & $\begin{array}{l}\text { As described above; may be } \\
\text { unnecessary if object } \\
<20 \mathrm{~mm} \text {. }\end{array}$ \\
\hline Magnet & $\begin{array}{l}\text { More than one ingested or } \\
\text { ingested with other metal } \\
\text { object(s). }\end{array}$ & $\begin{array}{l}\text { Refer for urgent endoscopic } \\
\text { removal/laparotomy, even if } \\
\text { asymptomatic. }\end{array}$ & All patients. & $\begin{array}{l}\text { As per endoscopic/ } \\
\text { laparotomy findings. }\end{array}$ \\
\hline $\begin{array}{l}\text { Electric cell (button } \\
\text { battery) }\end{array}$ & $\begin{array}{l}\text { High-voltage lithium-ion } \\
\text { cell; oesophageal impaction } \\
\text { may lead to full-thickness } \\
\text { electrical oesophageal burn } \\
\text { within } 2 \text { - } 3 \text { hours; narrow } \\
\text { negative pole anterior (risk } \\
\text { of perforation into aortic } \\
\text { arch, trachea). }\end{array}$ & $\begin{array}{l}\text { May be admitted and } \\
\text { observed as inpatient if } \\
\text { subdiaphragmatic on X-ray; } \\
\text { gentle laxative may be given } \\
\text { (e.g. lactulose/sorbitol). }\end{array}$ & $\begin{array}{l}\text { Urgent endoscopic } \\
\text { removal if symptomatic, } \\
\text { if supradiaphragmatic or } \\
\text { remains in stomach on } \\
\text { follow-up imaging } \\
>24 \text { hours; laparotomy } \\
\text { required if any signs of } \\
\text { peritonism; thoracotomy } \\
\text { with cardiac bypass if } \\
\text { comorbid upper GIT } \\
\text { bleeding. }\end{array}$ & $\begin{array}{l}\text { Abdominal X-rays } 8 \text { - } \\
\text { 12-hourly, with clinical } \\
\text { review till confirmed to } \\
\text { have passed out of rectum if } \\
\text { infradiaphragmatic. }\end{array}$ \\
\hline
\end{tabular}

Continued ... 
Table 1. (continued) Commonly ingested and potentially harmful non-food items and management principles ${ }^{[19,20,26]}$

\begin{tabular}{|c|c|c|c|c|}
\hline Ingested object/agent & $\begin{array}{l}\text { High-risk features for tissue } \\
\text { injury }\end{array}$ & Initial management & Referral criteria & Follow-up \\
\hline Strong alkali & $\begin{array}{l}\text { High risk for oesophageal } \\
\text { injury with stricture } \\
\text { formation, gastric injury } \\
\text { uncommon (e.g. 'lye'/caustic } \\
\text { soda/oven cleaner/hair } \\
\text { relaxant/industrial bleaching } \\
\text { agent of unknown strength). }\end{array}$ & $\begin{array}{l}\text { Keep nil by mouth (avoid } \\
\text { any neutralising agent); } \\
\text { exothermic reaction } \\
\text { increases tissue injury; do } \\
\text { not give activated charcoal. } \\
\text { Clear fluids may be given } \\
\text { as tolerated after grading } \\
\text { depth of mucosal injury, and } \\
\text { progress to a normal diet as } \\
\text { symptoms permit. } \\
\text { A chest X-ray may identify } \\
\text { concomitant aspiration } \\
\text { pneumonia, or rarely } \\
\text { pneumomediastinum or } \\
\text { pneumoperitoneum. }\end{array}$ & $\begin{array}{l}\text { Any symptoms (e.g. oral } \\
\text { burns, absence of oral } \\
\text { burns), but dysphagia/ } \\
\text { drooling and abdominal } \\
\text { pain with a history of } \\
\text { pH >11 ingestion mandate } \\
\text { evaluation for mucosal } \\
\text { injury with technetium- } \\
\text { 99-radiolabelled sucralfate } \\
\text { scinitigraphy and/or } \\
\text { endoscopic grading of } \\
\text { injury, ideally within } \\
\text { 24 - } 48 \text { hours. } \\
\text { Grading of injury to } \\
\text { identify patients at risk for } \\
\text { oesophageal stricture to } \\
\text { identify erosions/slough/ } \\
\text { eschar involving >50\% } \\
\text { of circumference allows } \\
\text { stratified follow-up with } \\
\text { surveillance endoscopy. } \\
\text { Negative technetium-99 } \\
\text { sucralfate scintigraphy } \\
\text { where available averts } \\
\text { endoscopy. } \\
\text { Proton-pump inhibitor and } \\
\text { oral antifungal therapy may } \\
\text { help mitigate secondary } \\
\text { injury to burnt oesophageal } \\
\text { mucosa. } \\
\text { Antibiotics only indicated in } \\
\text { full-thickness perforation. }\end{array}$ & $\begin{array}{l}\text { Endoscopically placed } \\
\text { nasogastric feeds may be } \\
\text { required until drooling } \\
\text { resolves and oral burns allow } \\
\text { oral intake. } \\
\text { Liquefactive necrosis leads to } \\
\text { rapid penetration into tissue; } \\
\text { submucosal fibrosis may lead } \\
\text { to luminal narrowing within } \\
3 \text { - } 6 \text { weeks. } \\
\text { Early programme of } \\
\text { oesophageal dilations } \\
\text { crucial for endoscopically } \\
\text { visualised injuries affecting } \\
>50 \% \text { of lumen and causing } \\
\text { erosions/slough; contrast } \\
\text { oesophagogram in } 3 \text { weeks if } \\
\text { window for early endoscopy } \\
\text { is missed to assess for } \\
\text { oesophageal irregularities } \\
\text { suggestive of early stricture } \\
\text { formation. } \\
\text { Weekly dilations for strictures } \\
\text { may initially be required, } \\
\text { lasting for several months; } \\
\text { treatment-refractory } \\
\text { strictures may require } \\
\text { oesophageal replacement } \\
\text { surgery. }\end{array}$ \\
\hline Strong acid & $\begin{array}{l}\text { Examples: car battery acid, } \\
\text { industrial agent; higher } \\
\text { risk for gastric perforation } \\
\text { with acids, but oesophageal } \\
\text { injury may also occur. }\end{array}$ & As described above. & & \\
\hline $\begin{array}{l}\text { Reducing/oxidising } \\
\text { reagent }\end{array}$ & $\begin{array}{l}\text { Potassium permanganate; } \\
\text { hydrogen peroxide, } \\
\text { bleaching agents (e.g. } \\
\text { sodium hypochlorite, } \\
\text { calcium hypochlorite). }\end{array}$ & As described above. & & \\
\hline Volatile agent & $\begin{array}{l}\text { Hydrocarbons (e.g. paraffin, } \\
\text { paint thinners, household } \\
\text { cleaning agents). }\end{array}$ & $\begin{array}{l}\text { Respiratory distress, } \\
\text { pulmonary crepitations, } \\
\text { tachypnoea; radiological } \\
\text { findings may lag behind } \\
\text { clinical features of aspiration } \\
\text { pneumonitis. } \\
\text { Central nervous system } \\
\text { and cardiac depression less } \\
\text { common. } \\
\text { Abdominal pain and nausea } \\
\text { common, but endoscopy } \\
\text { not indicated if substance is } \\
\text { known. }\end{array}$ & $\begin{array}{l}\text { Oxygen therapy and rarely } \\
\text { mechanical ventilator } \\
\text { support may be required. }\end{array}$ & $\begin{array}{l}\text { Resolution in } 48 \text { hours - } \\
1 \text { week. }\end{array}$ \\
\hline
\end{tabular}

